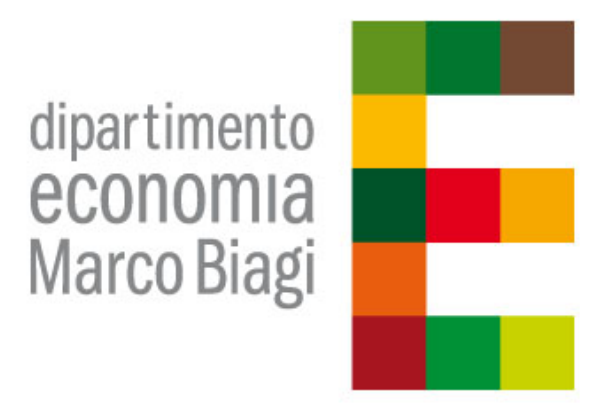

DEMB Working Paper Series

N. 129

Women Entrepreneurs in Italy: A Prosopographic Study

Alberto Rinaldi*, Giulia Tagliazucchi**

August 2018

* University of Modena and Reggio Emilia

RECent, Center for Economic Research

Address: Viale Berengario 51, 41121, Modena, Italy

Email: alberto.rinaldi@unimore.it

** University of Modena and Reggio Emilia

Address: Viale Berengario 51, 41121, Modena, Italy

Email: giulia.tagliazucchi@unimore.it

ISSN: 2281-440X online

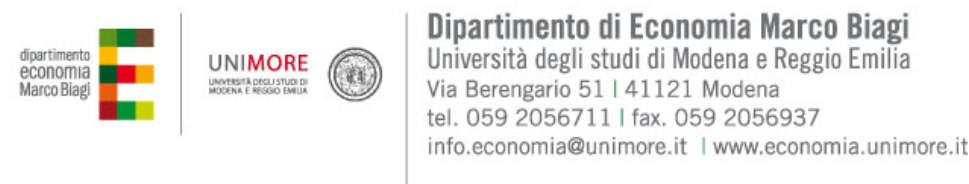




\title{
Women Entrepreneurs in Italy: A Prosopographic Study
}

\author{
Alberto Rinaldi ${ }^{1}$ \\ (Università di Modena e Reggio Emilia) \\ Giulia Tagliazucchi \\ (Università di Modena e Reggio Emilia)
}

\begin{abstract}
:
Women entrepreneurs have long been an understudied topic in business history. This paper contributes to fill this gap by analyzing Italian women's entrepreneurship from the mid-20 ${ }^{\text {th }}$ century to 2016 . It is based on a new dataset concerning the profiles of the 80 women who were successful entrepreneurs and became Cavalieri del Lavoro (Knights of Labour), i.e., they were decorated with the Ordine al "Merito del Lavoro" (Order of Merit for Labour), the highest recognition for achievements in the world of business in Italy. The dataset also includes a comparable balanced sample of men who obtained the same award to single out the main similarities and differences between men and women entrepreneurs. This paper employs a quantitative prosopographic approach: after presenting some descriptive statistics and some exemplary cases of women entrepreneurs, it uses cluster analysis to identify typological groups of women versus men entrepreneurs. This paper show that the institutional context and gender stereotypes slowed down the development of Italian women's entrepreneurial abilities. Women entrepreneurs tend to cluster in family firms and to have become entrepreneurs by inheritance, whereas they have been handicapped in all other fields relevant to entrepreneurial success: access to education (especially STEM), managerial career and experience abroad. Nonetheless, women entrepreneurs operated beyond women's niches tied to the traditional ideology of femininity, e.g., textiles, garment and services. Several women operated in sectors such as chemicals and engineering in which many Italian industrial districts are specialized.
\end{abstract}

Keywords: Women, history of entrepreneurship, Italy, quantitative prosopography

JEL CLASSIFICATION: J16, L26, M14, N84

${ }^{1}$ Corresponding author: alberto.rinaldi@ unimore.it.

Alberto Rinaldi acknowledges the support of the UNIMORE FAR grant 2016. 


\section{Introduction}

Despite self-employment and entrepreneurship have been central to women's economic agency, women's entrepreneurship is a vastly understudied topic in business history. Women have participated in the business world but have been absent from the dominant narratives of its history. Women's history emerged from the feminist movements in the 1960s and 1970s, but it was not until the 1990s that business history began to analyse women's engagement in business (Walsh, 2005). In that decade, some seminal books that addressed women's long-standing role as entrepreneurs were published (Kwolek-Folland, 1994, 1998; Gamber, 1997; Yeager, 1999). They were soon followed by special issues on gender and business history by such leading journals as Business History Review (1998, 2007), Enterprise \& Society (2001), and Management \& Organizational History (2010). Nonetheless, gendered business history kept on being treated as marginal and, for example, no chapter of The Oxford Handbook of Business History (2008) was devoted to women's entrepreneurship so that a qualified reviewer observed that in this book, other than some sketchy references to the role played by women in family firms, gender is conspicuous by its absence (Rowlinson, 2009).

Despite the paucity of studies available, some themes have been highlighted in the literature on the history of women's entrepreneurship. The first one is that entrepreneurship must be viewed as a gendered phenomenon. This perspective considers women's entrepreneurship as an economic form shaped by ideology about femininity and, conversely, masculinity. Gender is a cultural construction through which men and women define their identity, understand their economic affairs, make decisions and allocate resources (Scott, 1988; Rose \& Frader, 1996). As a result, deep-seated notions about "women's work" - that is, work appropriate for women or uniquely women's, usually conceived as an extension of women's traditional domestic culture - have shaped job possibilities, wages, and business opportunities for women. These assumptions have given women access to niche markets and, at the same time, they helped to marginalize their business environment (KwolekFolland, 2001). 
These segregated feminized business niches usually served a female clientele and used small-scale and labour-intensive forms of business organization (Murphy, 1991). This was the case of food and domestic services, dining, catering, laundry, dressmaking, clothing, retail luxury goods, and lodging (Kwolek-Folland, 1998). Traditional assumptions about women's domestic economic role maintained women's dominance in these industries and allowed them to expand into others, such as the cosmetic industry which became both a site of women's business activity and an actor that played a paramount role in defining the appearance of femininity in the $20^{\text {th }}$ century (Peiss, 1999).

A second major theme is the "family claim" (Rosenberg, 1992). It holds that the advent of capitalism in the Western world coincided with a dualistic gender system that accorded women a status connected to the privacy of family life and men a status framed by public engagement. As a result, women's relation to family was integral to their role in business, affording opportunities as well as imposing limitations (Honeyman, 2007). Thus, the law of coverture excluded married women from independent legal rights to property and business ownership, ${ }^{1}$ but women could nonetheless engage in any business concern if it occurred in the context of their family needs, e.g. as widows and mothers who held the family firm intact until a son or a son-in-law was able to take over (Kwolek-Folland, 1998). As a result, the family-based enterprise became a conduit for women to engage in allegedly "men's industries", such as metalworking and shipbuilding, and non-traditional activities like introducing innovations, taking risks, and managing large-scale enterprises (Berg, 1993; Doe, 2009; Kahn, 2016). Also today, many women entrepreneurs see their firms embedded in familial relationships and responsibilities (Jennings \& Brush, 2013).

A third theme stresses the different entrepreneurial styles of women as compared to men entrepreneurs. It has been argued that as they were working under different sets of social constraints and expectations, women entrepreneurs often organized and managed their firms differently from men (Phillips \& Rippin, 2010). In particular, women were pushed to extend to their public and entrepreneurial life the gender role traditionally assigned to them in the domestic sphere. As a result, women entrepreneurs more often pursued goals beyond economic gains (Jennings \& Brush, 2013). 
Thus, Holden (2010) introduced the notion of "social mothering" in which women's traditional mothering role was extended to philanthropic work in society as a whole. In this view, women entrepreneurs are expected to be maternal and thus prone to an entrepreneurial style that brings up other people's children. Hence, they show a higher propensity to social engagement and to be more active in promoting education, philanthropy and environmentally friendly businesses.

By contrast, Aston \& Di Martino (2017) argued that female business owners not only operated also in traditionally "male sectors", but they traded in ways similar to their male counterparts in terms of business size, risk-taking and, eventually, success. However, their conclusion is limited to the world of sole ownerships and partnerships, and cannot be extended to entrepreneurship in limited companies, where the presence of women was likely to be much less frequent.

Thus, the similarities and differences between men's and women's entrepreneurship remain a hotly debated theme that needs further investigation. This paper aims to shed light on it by focusing on the case of Italy. This paper relies on a new dataset concerning the biographies of the 80 women who were successful entrepreneurs and became Cavalieri del Lavoro (Knights of Labour), i.e. they were decorated with the Ordine al "Merito del Lavoro" (Order of Merit for Labour), the highest recognition in Italy for achievements in the world of business. The dataset also includes a comparable balanced sample of men who obtained the same award to single out the main similarities and differences between men and women entrepreneurs. We present a quantitative prosopography of these biographies, which is becoming an increasingly popular technique among economic and business historians (Nicholas, 1999; Mokyr, 2010; Toninelli \& Vasta, 2014; Nuvolari, Toninelli \& Vasta, 2018).

This paper is structured as follows: section 2 describes the source and data utilised in this study, while section 3 presents some descriptive statistics of both men and women entrepreneurs as well as some exemplary histories of women entrepreneurs. Section 4 refines the descriptive approach by using cluster analysis to produce entrepreneurial typologies that single out the main characteristics that distinguish men from women entrepreneurs. Lastly, section 5 provides some concluding remarks. 


\section{Sources and data}

The main source of this research is the biographies of the individuals who were awarded the honour of Cavalieri del Lavoro, which is the highest recognition in Italy for results obtained in the world of business. $^{2}$

This award was introduced by King Vittorio Emanuele III of Italy in 1901. Since the proclamation of the Republic in 1946, the decoration has been bestowed by the President of the Italian Republic, who appoints 25 new Knights of Labour each year, who can be either entrepreneurs or managers. Since 1901, 2,797 Knights of Labour have been appointed. However, we waited until 1964 to find the first woman, Gilberta Gabrielli Minganti (1897-1970), owner of the Officine Meccaniche Minganti e C. of Bologna (engineering), who became Knight of Labour. ${ }^{3}$

We have built a dataset concerning the biographical profiles of all the 80 women who became Knights of Labour from 1964 to 2016 and a comparable balanced sample of men who obtained this award. The latter was built by selecting through random drawing, for each year, a number of men equivalent to the number of women who had been appointed in that year. ${ }^{4}$

These biographies were classified according to a number of variables, chosen on the basis of suggestions coming from both history and theory. The following aspects have been considered: demographic variables (gender, dates and location of birth and appointment), human capital formation (education, training and working experience abroad), entrepreneurial drive (inheritance, founder, manager), networks (involvement in politics, membership of public or private - e.g. credit institutes, private foundations, volunteer organizations, trade associations, but excluding the boards of other companies - associations, social engagement), celebrity (entry in Italian Wikipedia). Moreover, following theoretical suggestions, we considered innovative performance, industry, and form of enterprise of activity. ${ }^{5}$

\section{Descriptive statistics}


Table 1 shows the time trend, i.e. the number of female nominees for decades from the $1960 \mathrm{~s}^{6}$ to the 2016 nominations, the latest available with full description of biographies at the time of writing. The number of men equals because they were selected through random drawing by year.

Table 1: Knights of Labour by Decade of Appointment

\begin{tabular}{|c|c|c|c|}
\hline & Women $*$ & Men $* *$ & Total \\
\hline 1960 s & 5 & 5 & 10 \\
\hline 1970 s & 3 & 3 & 6 \\
\hline 1980 s & 8 & 8 & 16 \\
\hline 1990 s & 9 & 9 & 18 \\
\hline 2000 s & 25 & 25 & 50 \\
\hline 2010 s & 30 & 30 & 60 \\
\hline Total & 80 & 80 & 160 \\
\hline
\end{tabular}

* Total population

** Balanced comparable sample

As can be seen, more than half of women have been appointed after the year 2000, especially in the last five years, with an average of 3-4 women per year. This trend may be a sign of an awareness gained over the years on the important role of women within the business world. It is also reasonable to suppose that only recently women had access to top management positions and engage in entrepreneurial activity as founders, breaking down the so-called glass-ceiling. Similarly, probably their more recent success in the business field is also linked to the gained easier access to high level of education. In fact, the first women appointed in the 1960s and 1970s had lower levels of education and none of them had a university degree. The percentage of graduated women slowly grows over time, starting with the group of women appointed in the 1990s. The number of degrees for the new century's decorations is more impressive, with a higher proportion (28 out of 55) of graduated over the number of women appointed. ${ }^{7}$ 
Nonetheless, the number of university graduates in our sample is much higher amongst men entrepreneurs than amongst women (49 vs. 32). Women have a higher number of graduates in humanities; whereas in all other types of degrees men are more numerous (see Table 2). In particular, a quarter of men have a STEM (science, technology, engineering, and mathemactics) degree (as compared to 11 percent of women), and the number of men graduated in engineering is an even higher proportion. In fact, in our sample we have 14 men engineers as compared to just one woman.

The presence of engineers within the mainly Northern Italian male business elite was strong since the beginning of the $20^{\text {th }}$ century: the then labour market required specific skills for accessing corporate top positions, in the wake of the rise of the technological trajectory of the second industrial revolution. The situation progressively started to balance out in the second half of the $20^{\text {th }}$ century, in favour of law graduates and graduates in the fields of economics and business administration. This change was spurred by the opening of recruitment of executives of state-owned enterprises (SOEs) to individuals born in the central and southern regions (Rinaldi, 2006). The successful establishment of the law and economics degrees is actually a phenomenon that has characterized all industrial societies during the process of growth and transformation of their business management systems due to the wave of corporate reorganization and financialization process that took momentum since the 1970s (Fligstein, 1990). In our sample, more than a quarter of the men got a degree in economics and business administration or jurisprudence.

Table 2: Knights of Labour by education

\begin{tabular}{|l|c|c|}
\hline & Women & Men \\
\hline Not university graduates & 48 & 31 \\
\hline
\end{tabular}




\begin{tabular}{|l|c|c|}
\hline University graduates: & 32 & 49 \\
- Humanities & 8 & 1 \\
- Jurisprudence & 5 & 11 \\
- Economics \& Bus. Adm. & 10 & 17 \\
- STEM & 9 & 20 \\
of which Engineering & 1 & 14 \\
\hline Total & 80 & 80 \\
\hline
\end{tabular}

Table 3 reports the distribution of the Knights of Labour in our sample according to the industry in which they had their entrepreneurial career. ${ }^{8}$ We can observe that men's distribution is more balanced than women's. In fact, there are some industries - especially the financial sector (banks and insurances) and utilities - in which we find very few women or no women at all and that stand out as male bastions. Women are more numerous than men in manufacturing (that accounts for 62.5 percent of total women) and services (24 percent of the total), i.e., wholesale and retail, transport and storage, residential and restaurant services, information and communication services. Another 9 percent of women entrepreneurs operates in agriculture.

Looking at the men entrepreneurs, as we have anticipated the two main differences concern utilities and the financial sectors. In fact, only men are involved in utilities, and another 13 men (as compared to just one woman) over the total of 80 operated in the bank and insurance sector. The only woman appointed for her manager career within the bank and insurance sector is Maria Bianca Farina (born in 1941 - appointed in 2016), who, at the time of her appointment, was president of Poste Italiane $S p A$ (Italy's main postal services provider) and president of the Poste Italiane Group insurance companies. With a degree in economics and business administration, she has dedicated her professional life almost entirely to the insurance and financial sector, holding positions of increasing responsibility. She is also president of ANIA, the association of Italian insurance companies, in which she has promoted a debate on issues of public interest, such as social security and welfare. Moreover, following the election of Pope Francis as Roman Catholic pontiff in 2013, she has also become a 
member of the Governing Council of the AIF, the authority that operates in the Vatican with functions of financial information and supervision. She is also involved in numerous social activities and has received numerous awards. She is also author on important Italian and international financial and insurance newspapers.

Table 3: Knights of Labour by industry

\begin{tabular}{|l|c|c|}
\hline & Women & Men \\
\hline Agriculture & 7 & 4 \\
\hline Manufacturing: & 50 & 41 \\
- Food and beverage & 6 & 6 \\
- Textiles and garment & 17 & 4 \\
- Engineering and electronics & 11 & 17 \\
- Other manufacturing & 7 & 3 \\
\hline Utilities & - & 3 \\
\hline Constructions & 3 & 6 \\
\hline Services & 19 & 13 \\
\hline Banks and insurance & 80 & 80 \\
\hline Total & & 13 \\
\hline
\end{tabular}

Looking more closely at the manufacturing sector, there are some further differences between women and men. The latter are predominantly involved in engineering and electronics ( 21 percent) and in chemicals (14 percent). Conversely, there is a much higher proportion of women entrepreneurs involved in such a typical "women's industry" as textiles and garment (21 percent), with enterprises born from entrepreneurial initiatives owned by the woman or with the support of her husband.

Nonetheless, we find also a sizeable number of women who were active in engineering and electronics (14 percent) and chemicals (11 percent) - two traditionally “men’s industries” and two of the main specializations of Italian industrial districts (Istat, 2015) ${ }^{9}-$ in which the woman surged to 
her entrepreneurial position mainly thanks to her ties with her family of origin or her husband's family. All of them operated in family firms, to stress the crucial role that family played as conduit for women not to be restricted - when it was needed for preservation and success of the family business itself - solely to those traditional "women's trades" viewed as an extension of their domestic skills.

Among them, Sonia Bonfiglioli (born in 1963 - appointed in 2015) is president of the family company (Bonfiglioli Riduttori SpA), founded by her father in the engineering industrial district of Bologna and active in the design, construction and distribution of a complete range of products for power transmission and drive systems. After her studies in mechanical engineering (she is the only female engineer among Knights of Labour), she obtained a master's degree in business administration; since 1992 she has been active into the family firm and her effort was dedicated to prompt the latter's internationalization. Through important acquisitions, she promoted its evolution and integration from a mechanical to an electronics firm. Today the company employs over 3,600 people and operates in 80 countries; the company's commitment is also strongly aimed at the social sphere. She also sits in several boards of directors and executive and management committees.

As to the chemical sector, an outstanding figure is Daniela Villa (born in 1953 - appointed in 2015), managing director of L'Erbolario Srl, a company headquartered in Lodi near Milan, which is the market leader in Italy in vegetable derived cosmetics. Graduated in biological sciences, she began to be interested in plants and their therapeutic properties from her young age. She opened her first herbalist with her husband, where working together they made their first cosmetics, thanks to the help of ancient family recipes. She then obtained a herbal medicine degree from the University of Urbino and led the team of the research and development laboratory of L'Erbolario. Over the years, she has dedicated herself to the research and study of manufacturing processes, forging collaborative relationships with important research institutions of Italian phytocosmetics. Over the years, L'Erbolario has been transformed from a small family-run business into an internationally renowned company. The company pays great attention to ethics and environmental sustainability, with a very 
short supply chain and a production entirely made in Italy. She has also received several awards and recognitions.

Beyond the traditional female and male characterization of industries, it seems also crucial to investigate the way through which men and women enter in the enterprise. In particular, Table 4 highlights three entrepreneurial drives. According to the biographies collected, we assess whether a man or a woman entered in the enterprise by inheritance (by his / her family o by partner's family), whether he / she founded the enterprise and, finally, whether he / she does not own the company and is a manager.

Table 4: Knights of Labour by entrepreneurial drive

\begin{tabular}{|l|c|c|}
\hline & Women & Men \\
\hline Inheritance: & 55 & 27 \\
- by birth family & 39 & 27 \\
\hline Founder: & 16 & Not specified \\
- individually & 20 & 31 \\
- with his wife / her husband & 11 & Not specified \\
\hline No owner (manager) & 5 & 22 \\
\hline Total & 80 & 80 \\
\hline
\end{tabular}

The first important point to notice is that for men entrepreneurs the biographies do not specify whether the enterprise was inherited through the partner's family. Similarly, no information is provided in the case of enterprise founding in collaboration with his wife. Looking strictly at the type of entrepreneurial drive, almost 69 percent of women became entrepreneurs by inheritance, against the 34 percent of men. Let us take into consideration, for example, one of the first women appointed: Angiola Maria Barbizzoli Migliavacca (1893-1982 - appointed in 1965) took her secondary school diploma at the Institute of Women's Magisterium and for most of her life she devoted herself to a 
career as a teacher. Serious family reasons led her to leave teaching and to become a collaborator of her husband; at his death, she replaced him assuming the position of managing director of the family firm Davide Campari SpA, a famous brand in the Italian beverage sector.

By contrast, a higher proportion of men entrepreneurs (39 percent) founded their own business, whereas just a quarter of women were founders of their firm, and more than a half of them in collaboration with her husband. One of them is Laura Biagiotti (1943-2017 - appointed in 1995), one of the great names of Italian fashion. The Laura Biagiotti brand, built in 40 years of activity together with her husband Gianni Cigna, and continued with her daughter Lavinia, includes ready-to-wear collections, accessories related to fashion and furnishings, appreciated throughout the world. Again, Elvira Giorgianni (1936-2010 - appointed in 1989), graduated in jurisprudence, at the end of the 1970s gave life, with her husband Enzo Sellerio, to the Sellerio publishing house. The company, in less than ten years, after a beginning characterized by an attention above all at Sicilian literature and art and at volumes for bibliophiles with reduced circulation, became a cultural enterprise of national caliber.

However, the most staggering data concern the no owner / manager characterization. While 27.5 percent of men are managers, the corresponding figure is only 6 percent for women and it brings further evidence of the "maleness" of business management, i.e., of the existence of a glass-ceiling that prevents women to have access to top management positions (Alpern, 1993). This fact is even more insightful if we consider that eight men in our sample worked in SOEs against just one woman, the above mentioned Maria Bianca Farina who received the decoration in 2016 for her contribution in the bank and insurance industry (see Table 5). This shows that the Italian state did not actually use SOEs as an instrument to prompt the formation of a female managerial class. ${ }^{10}$

Table 5: Knights of Labour by form of enterprise

\begin{tabular}{|l|c|c|}
\hline & Women & Men \\
\hline Private & 79 & 72 \\
\hline
\end{tabular}




\begin{tabular}{|l|c|c|}
\hline State-owned & 1 & 8 \\
\hline Total & 80 & 80 \\
\hline
\end{tabular}

Table 6 presents the summary of some dichotomous variables that have rebuilt, on the basis of biographies, areas of intervention for the improvement of the enterprise, according the Schumpeterian definition of innovation (Schumpeter 1934, 1939), plus the involvement in social engagement as a form of positive communication that promote the enterprise, according to a wider definition of innovation. In fact, feminist studies have demonstrated how the traditional Schumpeterian concept of innovation is gendered, implying that it has a strong male connotation. Thus, the innovation concept has been widened to cover more areas than technology and market and includes also service and social innovation, two areas of intervention that better suit the expectations that society has towards women (Alsos, Hytti \& Ljunggren, 2013).

Nearly a half of women entrepreneurs were actively involved in some form of social engagement, a much higher proportion than men. Philanthropic and volunteer activities, community development, education nurturing, promotion of art and culture appear as recurring traits in the biographies of women entrepreneurs and may have contributed significantly to the appointment of some of them as Cavalieri del Lavoro. For example, Silvana Fucito (born in 1950 - appointed in 2007), a small retailer for over 30 years in the paint sector, has become the protagonist of the fight against racket in Naples and throughout Italy. She is president of the "San Giovanni a Teduccio for legality" Association, which over time involved other municipalities and, with the support of the Italian Antiracket Federation, has recorded significant results in the fight against extortion.

Table 6: Knights of Labour by kind of innovation

\begin{tabular}{|l|c|c|}
\hline & Women & Men \\
\hline Product innovation & 21 & 18 \\
\hline Process innovation & 13 & 15 \\
\hline Diversification in other sectors & 12 & 18 \\
\hline
\end{tabular}




\begin{tabular}{|l|c|c|}
\hline Internationalisation & 20 & 38 \\
\hline New organisational models & 13 & 9 \\
\hline Market positioning & 47 & 72 \\
\hline Involvement in social engagement & 35 & 21 \\
\hline
\end{tabular}

Number of women / men over the total of 80

Women also seem to be very active in reinforcing the market positioning of the firm. Conversely, men entrepreneurs made an even greater effort in fostering the market positioning of the firm, and were also more actively involved in the processes of internationalization (e.g., exports, trade agreements, foreign direct investments).

Following Toninelli \& Vasta (2014), we attribute one point to each kind of innovation; thus we obtain a composite index of propensity to innovation, which assume a score between 0 and 7 , depending on the number of dichotomous variables assuming value 1 (= yes) among the seven possible categories described above. In Table 7 we present the results of this exercise which provides a reliable proxy of the innovative capacity of both women and men entrepreneurs. In general, the index of innovation tends to skew on the lower values, and nobody reaches the highest scores of 6 and 7. Most women entrepreneurs focus on one or two actions for enterprise improvement, that is, they have a score of 1 and 2, with an average of 2.0. For men entrepreneurs the scores are slightly higher, with the vast majority collecting scores of 2 or 3 with the average value being 2.4. It is likely that the entrepreneurs and managers in our sample mainly operated in a particular business function, perpetuating specific policies and actions in relation to one or a few of the many possible areas of action and intervention, although formally holding leadership roles with a wider view on the entire firm. The woman entrepreneur who has the highest innovation index is Paola Artioli (born in 1960 - appointed in 2015), who graduated in economics and business administration at the University of Rome and then did her post-graduate studies in business and tax law at the City of London Polytechnic in the UK. After working in legal consulting studies, she joined the family business, Aso Siderurgica, in the steel 
industrial district of Brescia. Under her guidance, the company carried out a policy of acquisitions to strengthen its market positions and overseas presence, as well as diversify production. Moreover, she undertook initiatives related to equal opportunities and balance of life and work times. She also conducted numerous training and promotion projects for female entrepreneurs.

Table 7: Knights of Labour by innovative intensity

\begin{tabular}{|l|c|c|}
\hline Innovation intensity & Women & Men \\
\hline 0 & - & 2 \\
\hline 1 & 29 & 13 \\
\hline 2 & 28 & 27 \\
\hline 3 & 17 & 30 \\
\hline 4 & 5 & 6 \\
\hline 5 & 1 & 2 \\
\hline 6 & - & - \\
\hline 7 & - & - \\
\hline Total & 80 & 80 \\
\hline
\end{tabular}

Finally, Table 8 presents a few other interesting statistics. The first one concerns the dichotomous variable that includes possible experiences abroad, whether studying, training or working in other companies. Only for two women there is an explicit trace of a period of training abroad. One is the above-mentioned Paola Artioli and the other is Nicoletta Spagnoli (born in 1955 - appointed in 2007), who, after graduating in pharmacy at the University of Perugia, had a period of specialization at the University of California in the USA. She then joined the family business, Luisa Spagnoli SpA, a leader in the production and distribution of clothing female, then led by her father. By contrast, the number of men who had experiences abroad is much higher, even if it counts for less than a quarter over the total sample. International mobility does not appear to be an indispensable competence for access to top positions, specifically for women of the generations under investigation, even if women's lower 
innovation score can be, at least to some extent, a consequence of their lower opportunities to have experiences abroad.

Another interesting point is to assess the involvement in social and political activities for both men and women entrepreneurs. As Table 8 shows, women are more involved into politics and social concerns than men, and this is heavily stressed in the biographies: it seems that this is more often a reason for the appointment of a woman as a Knight of Labour. The other variable assesses the celebrity status of the entrepreneurs, by considering the presence of a dedicated page on Italian Wikipedia. Also in this case, just a few women have dedicated descriptions in Italian Wikipedia, while the presence more than doubles for men, to probably underscore a higher public recognition of their role.

Table 8: Knights of Labour: Other interesting statistics

\begin{tabular}{|l|c|c|}
\hline & Women & Men \\
\hline Experience abroad & 1 & 14 \\
\hline Social and Political engagement & 35 & 21 \\
\hline Celebrity (entry in Italian Wikipedia) & 7 & 19 \\
\hline
\end{tabular}

\section{Cluster analysis}

We now perform a cluster analysis with the aim to identify typological groups of women and men entrepreneurs, and assess differences and similarities among them. The cluster analysis allows creating mutually exclusive groups based on the similarities among the entities (Hair, Black, Babin \& Anderson, 2014). We specifically adopt a hierarchical cluster algorithm that represents similarity as the average distance from all objects in one cluster to all objects in another, and the Gower index, which is suitable for treating quantitative and dichotomous variables. The dendogram is successively cut at an appropriate level, in order to isolate insightful typological groups of entrepreneurs (see 
Figure 1). In order to assess the robustness of the analysis, we repeat the analysis more times and cross-validate the results. Finally, clusters are profiled using descriptive statistics, and similarities and difference emerge out.

Figure 1: Dendogram and identification of three clusters

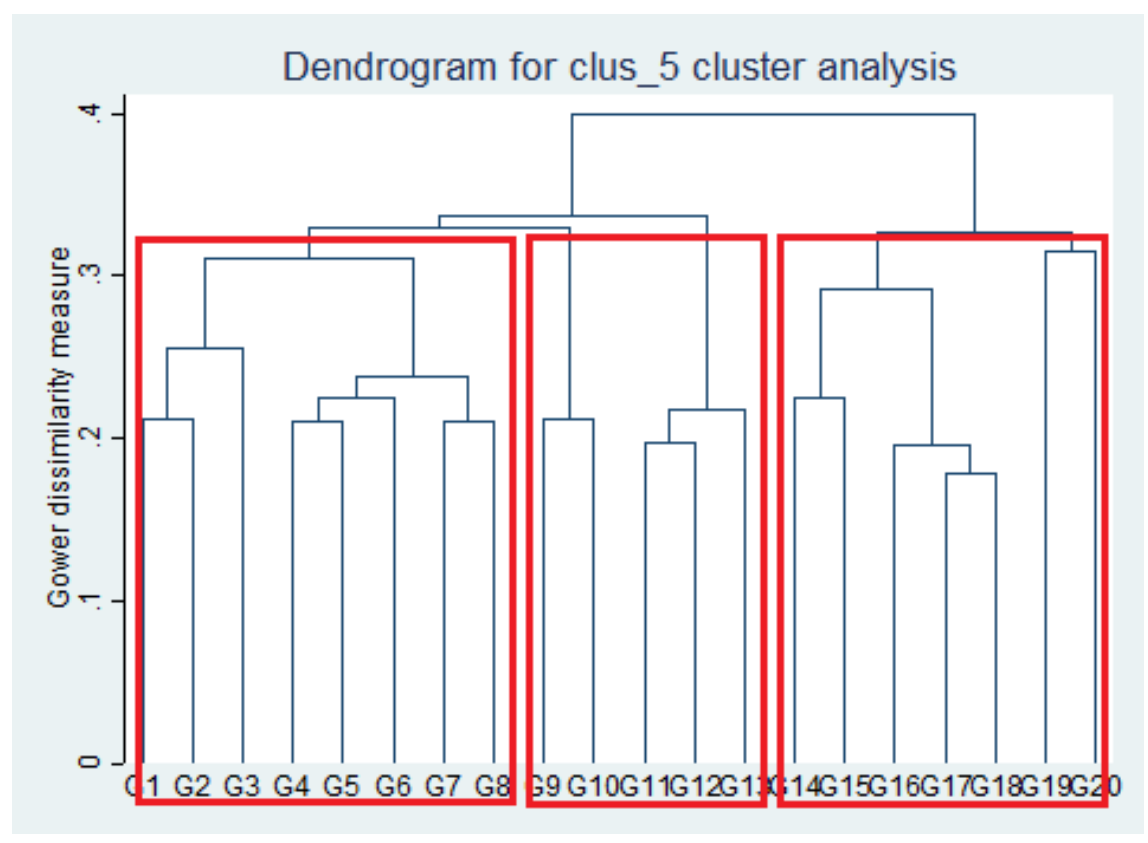

The cluster analysis identifies three groups of entrepreneurs. Two of them are quite similar in size, while the third is smaller. The gender composition is quite different among them (see Table 9), the first one is balanced between men and women, the second one has a substantial majority of women entrepreneurs (almost 67 percent), whereas the third one is composed almost exclusively of men and includes just one woman, who is the only female manager in the financial sector.

Table 9: Clusters gender composition

\begin{tabular}{|l|c|c|c|}
\hline & Men & Women & total \\
\hline Clus_1 & 33 & 31 & 64 \\
\hline Clus_2 & 26 & 48 & 74 \\
\hline
\end{tabular}




\begin{tabular}{|l|c|c|c|}
\hline Clus_3 & 21 & 1 & 22 \\
\hline Total & 80 & 80 & 160 \\
\hline
\end{tabular}

In Table 10 we summarize the most interesting statistics about the characterization of the clusters. The first important element that distinguishes the three groups is education. Clusters 1 and 3 have very high percentages of university graduates on the total, though in different areas: STEM and economics fields are predominant in the first group, while economics and jurisprudence predominate in the other. On the contrary, cluster 2 is characterized by the total absence of graduates; it gathers entrepreneurs with lower education levels. Another interesting point is the industry characterization of the groups. Manufacturing is the most represented industry in both clusters 1 and 2, even if in different specializations: engineering and electronics and chemicals in cluster 1; textiles and garment, plus some women entrepreneurs operating in chemicals and engineering, in cluster 2. On the one hand, this may be considered as an evidence of the gendered character of entrepreneurship; on the other hand, a substantial proportion of women entrepreneurs is found also in such traditionally “men's industries" as chemicals and, above all, engineering, in which many Italian industrial districts are specialized. It seems that women, if operating within family firms, can have access to the localized pools of knowledge that constitute the major competitive advantage of industrial districts also when they specialized in “men's industries", and use them to nurture their entrepreneurial drive. ${ }^{11}$ In addition to the manufacturing sector, services are an important specialization in cluster 1, as well as agriculture in cluster 2. Entrepreneurs active in banks and insurances and in utilities characterize the third group, which appears more distant from the others. As a further evidence of the dissimilarity of cluster 3 from the other groups, experience abroad has the highest value and proportion over the total in this group than in the other two. It seems that studying, training or working abroad is considerably more important for this cluster than for the other two, in other words it appears to be not essential for entrepreneurs but it is for managers. 


\begin{tabular}{|c|c|c|c|}
\hline & Clus_1 & Clus_2 & Clus_3 \\
\hline Education & $\begin{array}{l}\text { University degree (97\%) } \\
\text { - STEM }(45 \%) \\
\text { - Economics and business } \\
\text { administration (23\%) }\end{array}$ & University degree: 0 & $\begin{array}{l}\text { Degree }(86 \%) \\
\text { - Economics and business } \\
\text { administration }(55 \%) \\
\text { - Jurisprudence }(27 \%)\end{array}$ \\
\hline Industry & $\begin{array}{l}\text { Manufacturing }(56 \%) \\
\text { - Engineering }(20 \%) \\
\text { - Chemicals }(10 \%) \\
\text { Services }(26 \%)\end{array}$ & $\begin{array}{l}\text { Manufacturing (68\%) } \\
\text { - Textiles and garment (23\%) } \\
\text { - Engineering (16\%) } \\
\text { - Chemicals }(12 \%) \\
\text { Services (15\%) } \\
\text { Agriculture (11\%) }\end{array}$ & $\begin{array}{l}\text { Manufacturing (23\%) } \\
\text { - Engineering (18\%) } \\
\text { Banks and Insurances (50\%) } \\
\text { Services (18\%) } \\
\text { Utilities (9\%) }\end{array}$ \\
\hline Type of entrepreneurs & $\begin{array}{l}\text { Inheritance }(61 \%) \\
\text { Founder }(25 \%)\end{array}$ & $\begin{array}{l}\text { Inheritance (58\%) } \\
\text { Founder (39\%) }\end{array}$ & $\begin{array}{l}\text { Manager (73\%) } \\
\text { Founder (27\%) }\end{array}$ \\
\hline Family firms & Yes $(69 \%)$ & Yes $(76 \%)$ & No $(100 \%)$ \\
\hline $\begin{array}{l}\text { Schumpeterian } \\
\text { innovativeness } \\
\text { (from } 0 \text { to } 6 \text { ) }\end{array}$ & $\begin{array}{l}\text { Range 0-4 } \\
\text { Mean } 2.04\end{array}$ & $\begin{array}{l}\text { Range } 0-4 \\
\text { Mean } 1.81\end{array}$ & $\begin{array}{l}\text { Range } 0-3 \\
\text { Mean } 1.40\end{array}$ \\
\hline $\begin{array}{l}\text { Schumpeterian } \\
\text { innovativeness and } \\
\text { social engagement } \\
\text { (from } 0 \text { to } 7 \text { ) }\end{array}$ & $\begin{array}{l}\text { Range 1-5 } \\
\text { Mean } 2.40\end{array}$ & $\begin{array}{l}\text { Range 1-4 } \\
\text { Mean } 2.20\end{array}$ & $\begin{array}{l}\text { Range } 0-3 \\
\text { Mean } 1.60\end{array}$ \\
\hline
\end{tabular}

In fact, the entrepreneurial drive greatly differs among clusters. The first and the second groups are strongly characterized by inheritance, while the third group is quite exclusively characterized by the presence of managers. The founding of his / her own enterprise is also present in clusters 1 and 2, and with scant proportion in cluster 3. However, this entrepreneurial drive assumes a different connotation in these two groups due to the stronger presence of founding activities in collaboration with the partner (husband) in cluster 2. As a result, family ties appear to be crucial for the development of 
Italian women's entrepreneurial capabilities and activities. This assumption is further corroborated by the higher presence of family firms in cluster 2 than in cluster 1, whereas family firms are completely absent in cluster 3 .

Finally, some considerations on the innovation propensity of entrepreneurs: here the most insightful differences emerge out from the index comparison of clusters 1 and 2. Even if the index is mainly centered on the lower points, it is subject to slightly change in connection with the education level, ceteris paribus. In addition, range and mean raise a little passing from a Schumpeterian definition of innovation to a broader one, which takes into consideration social engagement as a means of positive reinforcement of enterprise image promoted principally by women. In cluster 3 , dominated by managers active in the financial and utilities sectors and with nearly no women, the innovativeness scores remain stable at the lowest points.

\section{Conclusions}

This paper has investigated the main similarities and differences between women's and men's entrepreneurship in Italy by relying on a dataset based on the biographies of two comparable samples of women and men who were decorated with the Ordine al Merito del Lavoro, the highest recognition for achievements in the world of business in the nation. The paper provides a quantitative prosopography of these biographies, a technique that is becoming increasingly popular among economic and business historians.

Our main results show a strong evidence in favour of the "family claim". Family is the only institution in which Italian women entrepreneurs seem to have found a space. Kinship and family ties were often of a paramount importance in allowing a woman to become an entrepreneur and in many cases, a male figure (father or husband) acted as a guarantor for the female entrepreneur towards stakeholder and the business community. Moreover, the in-depth analysis of women entrepreneurs' biographies reveals that in several cases the inheritance and the generational change followed a traumatic and 
unexpected event that hit the family itself and forced the woman to assume the role of her father, husband, or brother.

Family firms played a crucial role as conduit for women not to be restricted solely to those traditional “women's niches" shaped by the ideology about femininity. In fact, we have found several women who run firms operating in what are considered "men's industries", such as chemicals and, above all, engineering, in which many Italian industrial districts are specialised. Moreover, also when operating in "men's industries", women entrepreneurs deeply exploited their competencies and introduce more "feminine" kinds of innovation; in particular, they showed a higher propensity to social engagement than their male counterparts. That is, it seems there has been a sort of contamination of "female" competencies into "male" domains.

By contrast, women were handicapped and marginalised in all the other fields relevant to entrepreneurial success: access to education (especially STEM and engineering), access to managerial career, and training abroad, with negative implications for women's - and the whole economy's innovative performance. Gender stereotypes and the glass-ceiling seem particularly strong in such sectors as financial intermediation and utilities that are dominated by managerial enterprises and where there is virtually no space for family firms. Also the state did not use SOEs as an instrument to prompt the formation of a female managerial class.

\section{REFERENCES}

Alpern, S. (1993). In the Beginning: A History of Women in Management. In E.A. Fagenson (Ed.), Women in Management: Trends, Issues, and Challenges in Managerial Diversity (pp. 19-51). Newbury Park, CA: SAGE. 
Alsos, G.A., Hytti, U., \& Ljunggren, E. (2013). Gender and Innovation: State of the Art and Research Agenda. International Journal of Gender and Entrepreneurship, 5(3), 236-256.

Aston, J., \& Di Martino, P. (2017). Risk, Success, and Failure: Female Entrepreneurship in Late Victorian and Edwardian England. The Economic History Review, 70(3), 837-858.

Berg, M. (1993). Women's Property and the Industrial Revolution. Journal of Interdisciplinary History, 24(2), 233-250.

Castagnoli, A. (2007). The Female Entrepreneur's Point of View and the Italian Economy. Business and Economic History On-Line, 5 (http://www.thebhc.org/publications/BEHonline/2007/castagnoli.pdf)

Colli, A., \& Rinaldi, A. (2015). Istitutions, Politics, and the Corporate Economy. Enterprise \& Society, 16(2), $249-269$.

Curli, B. (2002). Women Entrepreneurs and Italian Industrialization: Conjectures and Avenues for Research. Enterprise \& Society, 3(4), 634-656.

Doe, H. (2009). Enterprising Women and Shipping in the Nineteenth Century, Woodbridge, UK: The Boydell Press.

Fligstein, N. (1990). The Transformation of Corporate Control, Cambridge, MA: Harvard University Press.

Frader, L.L., \& Rose, S.O., (Eds) (1996). Gender and Class in Modern Europe, Ithaca, N.Y.: Cornell University Press.

Gamber, W. (1997). The Female Economy: The Millinery and Dressmaking Trades, 1860-1930, Urbana and Chicago, IL: University of Illinois Press.

Hair, J., Black, W., Babin, B., \& Anderson R. (2014). Multivariate data analysis, Harlow, UK: Pearson.

Heemskerk, E.M., \& Fennema, M. (2014). Women on Board: Female Board Membership as a Form of Elite Democratization. Enterprise \& Society, 15(2), 252-284.

Holden, K. (2010). Other people's children: Single women and residential childcare in mid-20 $0^{\text {th }}$ century England. Management \& Organizational History, 5(3-4), 314-330.

Honeyman, K. (2007). Doing Business with Gender: Service Industries and British Business History. Business History Review, 81(3), 471-493.

Istat (2015). $9^{\circ}$ Censimento dell'industria e dei servizi e Censimento delle istituzioni non profit. I distretti industriali 2011, Rome, Italy: Istat.

Jennings, J.E., \& Brush, C.G. (2013). Research on Women Entrepreneurs: Challenges to (and from) the Broader Entrepreneurship Literature? The Academy of Management Annals, 7(1), 663-715. 
Kahn, B.Z. (2016). Invisible Women: Entrepreneurship, Innovation, and Family Firms in Nineteenth-Century France. The Journal of Economic History, 76(1), 163-195.

Kwolek-Folland, A. (1994). Engendering Business: Men and Women in the Corporate Office: 1870-1930, Baltimore, MA: Johns Hopkins University Press.

Kwoled-Folland, A. (1998). Incorporating Women: A History of Women and Business in the United States, New York, N.Y.: Twayne Publishers.

Kwolek-Folland, A. (2001). Gender and Business History. Enterprise \& Society, 2(1), 1-10.

Marshall, A. (1890). Principles of Economics, London: Macmillan.

Mokyr, J. (2010). Entrepreneurship and the Industrial Revolution in Britain. In D.S. Landes, J. Mokyr \& W.J. Baumol (Eds), The Invention of Enterprise (pp. 183-210). Princeton, CA: Princeton University Press.

Murphy, L.E. (1991). Business Ladies: Midwestern Women and Enterprise, 1850-1880. Journal of Women's History, $3(1), 65-89$.

Nicholas, T. (1999). Clogs to Clogs in Three Generations? Explaining Entrepreneurial Performance in Britain since 1850. The Journal of Economic History, 59(3), 688-713.

Nuvolari, A., Toninelli, P.A., \& Vasta, M. (2018). What Makes a Successful (and Famous) Entrepreneur? Historical Evidence From Italy (XIX-XX Centuries). Industrial and Corporate Change, 27(3), 425-447.

Peiss, K. (1998). Hope in a Jar: The Making of America's Beauty Culture, New York, N.Y.: Metropolitan Books.

Phillips, M., \& Rippin, A. (2010). Striving to uncover a lost heritage: Reclaiming women in management and organization history. Management \& Organizational History, 5(3-4), 283-295.

Rinaldi, A. (2006). Entrepreneurs and Managers (1913-1972). In R. Giannetti \& M. Vasta (Eds), Evolution of Italian Enterprises in the 20 $0^{\text {th }}$ Century (pp. 239-263). Heidelberg, Germany-New York, N.Y.: Physica Verlag.

Rosenberg, R. (1992). Divided Lives: American Women in the 20 ${ }^{\text {th }}$ Century, New York, N.Y.: Hill and Wang / Farrar, Straus and Giroux.

Rowlinson, M. (2009). The Oxford Handbook of Business History (Review). Business History, 51(2), $292-294$.

Schumpeter, J.A. (1934). The Theory of Economic Development, Cambridge, MA: Harvard University Press.

Schumpeter, J.A. (1939). Business Cycles. A Theoretical, Historical, and Statistical Analysis of the Capitalist Process, New York, N.Y, and London, UK: McGrow-Hill Book Company Inc. 
Scott, J.W. (1988). Gender and the Politics of History, New York, N.Y.: Columbia University Press.

Toninelli, P.A., \& Vasta, M. (2014). Opening the black box of entrepreneurship: The Italian case in a historical perspective. Business History, 56(2), 161-186.

Ungari, P. (1974). Storia del diritto di famiglia in Italia (1796-1962), Bologna, Italy: Il Mulino.

Walsh, M. (2005). Gendered Endeavours: women and the reshaping of business culture. Women's History Review, 14(2), $181-202$

Yeager, M.A. (Ed.) (1999). Women in Business, Cheltenham, UK: Edward Elgar.

\footnotetext{
${ }^{1}$ The law of coverture was abolished between the 1850s and the 1880s in various American states, in 1882 in the UK and in 1919 in Italy (Curli, 2002).

${ }^{2}$ These biographies were drawn up by the Federazione Nazionale dei Cavalieri del Lavoro (National Federation of Knights of Labour) on the basis of interviews with the appointees. Thus, the biographies express the Knights of Labour's views and self-perceptions.

${ }^{3}$ www.cavalieridellavoro.it/english (last visit on 24 July 2017).

${ }^{4}$ The Cavalieri del Lavoro dataset is presently the only source that provides a sizeable number of entries of women entrpreneurs. The Dizionario Biografico degli Imprenditori Italiani (Biographical Dictionary of Italian Entrepreneurs) the source used in a recent prosopographic study on the economic and reputational dimensions of entrepreneurial success in Italy - has led to the completion of 608 entries overall, but only 10 of them are women (Nuvolari, Toninelli \& Vasta, 2018).
}

${ }^{5}$ As the honour of Cavaliere del Lavoro was a recognition for achievements in the world of business, all those (both men and women) who obtained it were successful stories. In this sense, our dataset suffers from a bias with respect from what would have resulted from the "ideal" but impossible construction of a fully representative random sample. Still, we believe it can provide many insights on similarities and differences between men and women entrepreneurs.

${ }^{6}$ The appointment of the first women in the 1960s was probably, at least in part, the result of the action of AIDDA (Associazione Imprenditrici e Donne Dirigenti d'Azienda $=$ Association of Italian Female Entrepreneurs and Business Executives), the first entrepreneurial association of women in Italy, that was founded in 1961. The aim of AIDDA was to highlight the contribution of women in top management, and to build an organization able to overcome the prejudices about the achievements of women in the field of work (Castagnoli, 2007). 
${ }^{7}$ As we have seen, until 1919 the requirement of husband's authorization barred married women from independently owning property and from the independent right to make donations, alienate buildings, contract mortgages, or cede or collect capital, as well as from related transactions and juridical procedures and, consequently, from independent management of bank accounts. After that law was repealed, Italian women were admitted to the independent professions, most public offices, and to the upper grades of the civil service (except those relating to defence and the "dignity of a high official of the State", such as the judiciary and the diplomatic service) (Ungari, 1974). Nonetheless, social norms and gender stereotypes marked to a large extent by catholic paternalistic culture, which is considered the most resilient informal institution in the whole Italian history, continued to heavily obstacle women's involvement in entrepreneurial activity.

${ }^{8}$ Industries have been reclassified in six macro-areas according to the Italian official definitions of Istat-Ateco 2007: agriculture, manufacturing, utilities, constructions, services, banks and insurance.

${ }^{9}$ The presence of a large sector of small and medium-sized firms often clustered in industrial districts represents a longterm and probably the most outstanding trait of Italy's industrial structure (Colli \& Rinaldi, 2015).

${ }^{10}$ Thus, the Italian government seems to have behaved in an opposite way to the Dutch government that, since the 1970s, started to purposely appoint women in the boards of directors of SOEs, thereby prompting an opening and democratization of the corporate elite (Heemskerk \& Fennema, 2014).

${ }^{11}$ On the role of localized pools of knowledge as one of the main competitive advantages in industrial districts, see Marshall (1890). 